\title{
Comparative biometrics of Saurel Trachurus trachurus (Lin- naeus, 1758) (Perciformes Carangidae) in the Algerian coast lines
}

\author{
Souheila Azzouz ${ }^{\prime *}$, Ali Tahar² \& Lyamine Mezedjri \\ ${ }^{1}$ Department of Biology, Faculty of Sciences, Badji Mokhtar University, 23000 Annaba, Algeria; e-mail: azzouz.souhi@yahoo.fr \\ ${ }^{2}$ Department of Natural Sciences and Life, Faculty of Sciences, University August 20, 195521000 Skikda, Algeria; e-mail: me- \\ zedjri.lyamine@gmail.com \\ "Corresponding author
}

\begin{abstract}
During 2012-2013, a comparative biometric study was conducted on a coastal marine teleost fish of the Carangidae family Trachurus trachurus (Linnaeus, 1758). The comparison is made on the basis of seven samples obtained along the Algerian coastline. From East to West: Elkala, Annaba, Skikda, Collo, Jijel, Algiers, and Oran, carrying out 36 morphometric and meristic measurements on each fish. ANOVA Fixed-Variance Analysis of Variance shows the existence of significant differences between the seven sites for 36 variables, as well as the existence of a sexual dimorphism for 22 measured variables and the absence of significant differences for 14 variables out of a total of 36 studied variables. The comparison between the seven sites by MANOVA multivariate statistical tests confirms the results obtained by the ANOVA.
\end{abstract}

KEY WORDS Algerian littoral; biometric study; Trachurus trachurus; univariate statistical test.

Received 18.03.2018; accepted 19.06.2018; printed 30.09.2018; published online 05.10.2018

\section{INTRODUCTION}

The study of the biometric or morphometric characters of the pelagic fish Saurel Trachurus trachurus (Linnaeus, 1758) (Perciformes Carangidae) by using morphometric and meristic measured variables on samples obtained along the Algerian littoral is the object of our research. In addition, it is the subject of numerous studies devoted to the various aspects of the biology of this species, T. trachurus, among which we may mention those of Letaconnoux (1951), Macer (1977), Porumb \& Porumb (1979), Korichi (1988), Arias \& Drake (1990), Benzohra \& Millot (1995), Choulika (2002), Mézédjri (2003), Grimes (2010), Slamene et al. (2012).
This study deals with the biometric comparison of seven sites of the Algerian littoral. Thus, the existence of a sexual dimorphism between males and females of the fish.

\section{MATERIAL AND METHODS}

\section{Data collection}

This study is carried out on fishes caught by using sardine nets and purse seines as fishing gear, trawlers, and small crafts.

The biometric study is based on seven samples obtained on the Algerian coast. From East to West: 
El-kala, Annaba, Skikda, Collo, Jijel, Algiers, and Oran (Fig. 1).

A minimum sample of 30 individuals is taken into consideration at each site, respecting as much as possible all present size classes. Each individual is wrapped in a plastic film immediately after collection to avoid damage, and it is put in the freezer at $-20{ }^{\circ} \mathrm{C}$. In the laboratory, a series of 36 morphometric and meristic measurements are made on each fish (Table 1; Fig. 2). These measurements were made on the basis of previous studies to obtain as much information as possible on these fishes studied. All metric measurements are made, to the nearest millimeter, using a dry point compass. The meristic measurements are made, under a binocular loupe, by means of a count. Sex determination was performed after fish dissection.

\section{Statistical data analyses}

Univariate statistical analyses. To describe well the different characteristics obtained in the sites, we calculated some basic statistical parameters such as the arithmetic mean $(\mathrm{x} \overline{)}$, the variance $(\mathrm{s} 2)$, and the standard deviation (s).

To compare the averages for each of the 36 characteristics between the seven sites, we used the oneway, fixed-ranking model of the variance analysis. The gender factor is completely hierarchical to the site factor. This test consists in comparing the averages of several populations at random, simple and

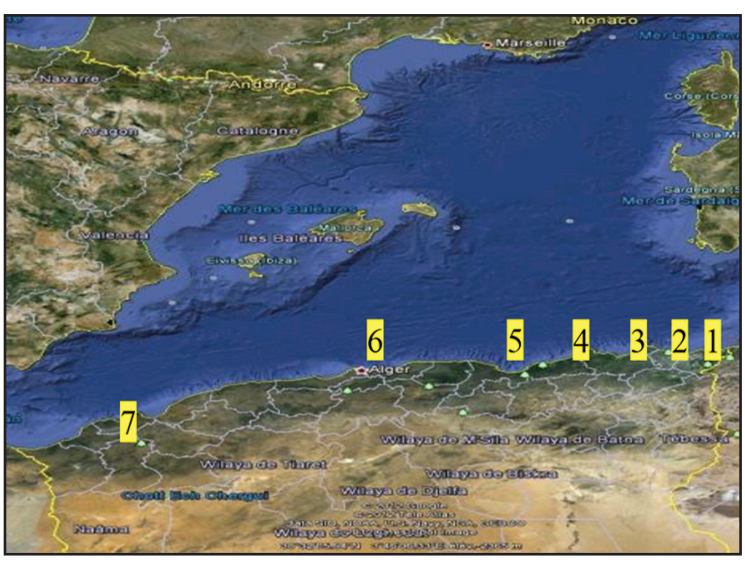

Figure 1. Location of study sites of the Algerian littoral: El Kala Gulf (1), Gulf of Annaba (2), Gulf of Skikda (3), Gulf of Collo (4), Gulf of Jijel (5), Bay of Algiers (6), Gulf of Oran (7). independent random samples (Dagnélie, 1970, 2006).

This ANOVA univariate analysis of variance analysis was used to compare, on one hand, between the 7 sites, and on the other hand, between the sexes in the sites, the averages of the 36 variables.

The calculations are performed by using the Minitab software GLM procedure (Minitab s.s., 2013) for each of the 36 variables at the 7 sites.

Multivariate statistical analyses. The multivariate variance analysis or the dispersion analysis aim to compare the averages of more than two populations for several variables.

This method is an extension of the univariate variance analysis, in which we have several variables that were observed simultaneously on the same individuals.

The comparison of the 7 sites and between sexes in the sites for all 36 studied variables, was performed by using MANOVA multivariate variance analysis using three statistical tests which are: Wilk's lambda, Lawley-Hotteling, and Pillai's trace (Dagnélie, 1970, 1986, 2006).

The three tests cited above and proposed by Palm (2000) and Dagnélie $(1970,2006)$ are all asymptotically equal in power and no test can be recommended in a systematic way, in preference to others (Dagnélie, 1986). According to Huberty (1994), the Wilk's test is the most popular.

All calculations were performed by a statistical analysis of Minitab Version 16 and statistical processing software (Minitab s.s., 2013).

The bibliography consulted for this work, in addition to the one mentioned, is listed as follows: Letaconnoux (1951); Macer (1977); Porumb \& Porumb (1979); Korichi (1988); Arias \& Drake (1990); Benzohra \& Millot (1995); Choulika (2002); Mézédjri (2003); Grimes (2010); Slamene et al. (2012); FAO (2013); Abla et al. (2018).

\section{RESULTS AND DISCUSSION}

\section{Univariate statistical analyses}

To better describe the different variables that characterize individuals (fish) studied in seven different sites and for each gender, we calculated some basic statistical parameters such as arith- 
metic mean (x), which is a position parameter and central tendency, the standard deviation (s) which measures the dispersion of data around the mean $(\mathrm{x})$, and the number that tell us about the importance of the data processed. The results of the description of the data obtained for the various variables and for a total of 334 studied fishes comparing between the seven sites of the Algerian coastline shows that the number of males is greater than the number of females for the sites of the Gulf of El-kala, Skikda, and Collo, while we note the opposite for the sites of the Gulf of Annaba, Jijel, Algiers, and Oran.

In contrast, the results obtained for the description of data by sex (sites) shows that the averages for the different variables are slightly higher for females than for males, except for the Gulf of Skikda, in which we note the reverse, with the averages of males higher than females. This may suggest a possible sexual dimorphism.

The comparison, firstly of the seven sites between them and, secondly, of both sexes in each site between them, was performed, and for each variable, using the univariate analysis of variance with two criteria fixed classification (sex and site) hierarchical model. The use of the univariate analysis variance ANOVA, and the results are obtained by using the GLM command of the MINITAB software.

The results of the ANOVA applied to each of the 36 variables measured are included in Table 2 to the comparison between the sites and between two sexes in the sites.

We now have to compare between the seven sites the equality of the averages of each measured characteristic.

Examination of Table 2 shows the existence of very highly significant differences between the 7 sites for all 31 morphometric measured variables and the meristic variables with the exception of one variable: Brsu, where the differences are highly significant at the level $\alpha=1 \%$.

Moreover, the examination of Table 2 shows the absence of significant differences for 14 out of 36 variables. The variables that show significant differences at the $\alpha=5 \%$ level are Lt, Lppc, Lcep, Lpdo, Poor, Pror, Lcra, Lapc., Hpv, Hdo, Hpdc, Baan, dopc, pcpv, pvan. Variables where the differences are highly significant are: Lf, Lppv, Dopv, Lpop, Bado. The variables doan and Hpc have very highly significant differences at the level $\alpha=0.1 \%$.

\begin{tabular}{|c|c|c|}
\hline Number & Code & Description \\
\hline \multicolumn{3}{|c|}{ Morphometric measurements } \\
\hline 1 & $\mathrm{Lt}$ & Total length \\
\hline 2 & Lf & At fork length \\
\hline 3 & Ls & Standard length \\
\hline 4 & Lpan & Length pre-anal \\
\hline 5 & Lppv & Length pre-pelvic \\
\hline 6 & Lppc & Length pre-pectoral \\
\hline 7 & Lcep & Cephalic length \\
\hline 8 & Lpdo & Length pre-dorsal \\
\hline 9 & Dopv & Dorsal / pelvic distance \\
\hline 10 & Doan & Dorsal / anal distance \\
\hline 11 & Doca & Dorsal / Caudal Distance \\
\hline 12 & Lman & Mandible length \\
\hline 13 & Lmax & Maxillary length \\
\hline 14 & Poor & Distance post-orbitaire \\
\hline 15 & Dor & Diameter Orbital \\
\hline 16 & Pror & Length Pre-orbital \\
\hline 17 & Lpop & Length pre-operculum \\
\hline 18 & Lain & Inorbital Width \\
\hline 19 & Lcra & Head width \\
\hline 20 & Mist & Length mandible / isthmus \\
\hline 21 & Lapc & Distance between pectoral insertions \\
\hline 22 & $\mathrm{Hpc}$ & Pectoral Height \\
\hline 23 & Hpv & Pelvic Height \\
\hline 24 & Hdo & Dorsal Height \\
\hline 25 & Han & Anal Height \\
\hline 26 & Hpdc & Peduncle Height \\
\hline 27 & Bado & Dorsal Height \\
\hline 28 & Baan & Anal Height \\
\hline 29 & Dopc & Distance dorsal/pectoral \\
\hline 30 & Pcpv & Distance pectoral/pelvic \\
\hline 31 & Pvan & Distance pelvic/anal \\
\hline \multicolumn{3}{|c|}{ Meristic counting } \\
\hline 32 & $\mathrm{Cæc}$ & Cæc Number of pyloric caecum \\
\hline 33 & Brin & $\begin{array}{l}\text { Number of lower gill rakers of the } \\
\text { 1st left branchial arch }\end{array}$ \\
\hline 34 & Brsu & $\begin{array}{l}\text { Number of upper gill rakers of the } \\
\text { lst left branchial arch }\end{array}$ \\
\hline 35 & Rypc & Number of rays of the left chest \\
\hline 36 & Rypv & Number of left pelvic rays \\
\hline
\end{tabular}

Table 1. Morphometric and meristic variables studied.

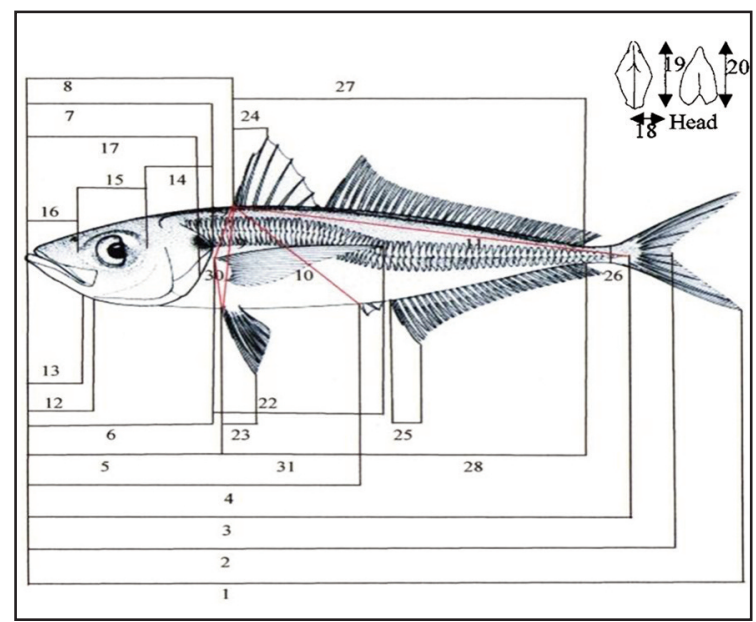

Figure 2. Morphometric measurements taken on each fish. 
This leads us to conclude the existence of a sexual dimorphism between males and females for the 22 variables mentioned above.

\section{Multivariate statistical analyses}

The MINITAB MANOVA command applied to the data obtained from the seven sites to perform the multivariate analysis with two fixed classification criteria and whose sex factor is hierarchical in the site factor, gives the results represented by Tables 3,4 .

For each of the two tables, the three Wilk's, Lawley-Hotelling, and Pillai's tests yield the same results. That is to say, the examination of Table 3 shows that the 3 tests conclude that there are very highly significant differences between the 7 sites, for all the morphometric and meristic observed characters on the T. trachurus.

In addition, the examination of Table 4 shows that the 3 tests lead to the absence of significant differences between the two sexes for each of the 7 sites for all 36 studied variables.

In the first case as in the second case, the MANOVA tests completely confirm the results of the univariate analysis of variance (ANOVA) obtained previously.

The significant differences found between the seven sites depend on several factors. It may be related to the dominant ecological factors in each region or they can also be due to the sampling period. The climate, the hydrodynamics, and water courses in each region are a source of nutrients for phytoplankton, which is the base of the trophic chain. In addition, the temperature differences between the different chosen stations can lead to significant differences and impact on reproduction.

\section{CONCLUSIONS}

This work deals with morphometry (biometrics) of the Carangid pelagic fish on the Algerian coastline from East to West, Saurel T. trachurus.

The comparative biometric study between seven sites (El-kala, Annaba, Skikda, Collo, Jijel, Algiers, and Oran) shows that the use of the generalized linear model or the ANOVA analysis applied to each of the 36 measured variables, whether for the site factor or the sex factor in site, reveals the significant

\begin{tabular}{|c|c|c|c|c|c|}
\hline \multicolumn{6}{|c|}{ Factors } \\
\hline \multirow[b]{2}{*}{$\mathrm{n}^{0}$} & \multirow[b]{2}{*}{ Variables } & \multicolumn{2}{|c|}{ Sites } & \multicolumn{2}{|c|}{ Sexes (sites) } \\
\hline & & F & $P$ & F & $P$ \\
\hline 1 & $\mathrm{Lt}$ & 71.10 & $0.000^{* * *}$ & 2.63 & $0.012 *$ \\
\hline 2 & Lf & 72.59 & $0.000 * * *$ & 2.82 & $0.007^{* *}$ \\
\hline 3 & Ls & 53.18 & $0.000^{* * *}$ & 0.90 & $0.504 \mathrm{~ns}$ \\
\hline 4 & Lpan & 55.66 & $0.000^{* * *}$ & 2.01 & $0.054 \mathrm{~ns}$ \\
\hline 5 & Lppv & 52.19 & $0.000 * * *$ & 2.97 & $0.005^{* *}$ \\
\hline 6 & Lppc & 65.96 & $0.000 * * *$ & 2.41 & $0.021^{*}$ \\
\hline 7 & Lcep & 63.10 & $0.000^{* * *}$ & 2.31 & $0.026^{*}$ \\
\hline 8 & Lpdo & 55.00 & $0.000 * * *$ & 2.67 & $0.011^{*}$ \\
\hline 9 & dopv & 27.04 & $0.000 * * *$ & 2.93 & $0.006^{* *}$ \\
\hline 10 & doan & 40.53 & $0.000 * * *$ & 3.98 & $0.000^{* * * *}$ \\
\hline 11 & doca & 52.25 & $0.000 * * *$ & 0.90 & $0.511 \mathrm{~ns}$ \\
\hline 12 & Lman & 18.17 & $0.000 * * *$ & 1.38 & $0.212 \mathrm{~ns}$ \\
\hline 13 & Lmax & 4.20 & $0.000^{* * *}$ & 0.99 & $0.437 \mathrm{~ns}$ \\
\hline 14 & Poor & 44.59 & $0.000^{* * *}$ & 2.67 & $0.011^{*}$ \\
\hline 15 & Dor & 29.16 & $0.000 * * *$ & 0.99 & $0.436 \mathrm{~ns}$ \\
\hline 16 & Pror & 31.55 & $0.000 * * *$ & 2.16 & $0.038 *$ \\
\hline 17 & Lpop & 48.57 & $0.000 * * *$ & 2.82 & $0.008 * *$ \\
\hline 18 & Lain & 19.72 & $0.000 * * *$ & 1.58 & $0.142 \mathrm{~ns}$ \\
\hline 19 & Lcra & 42.55 & $0.000 * * *$ & 2.16 & $0.038 *$ \\
\hline 20 & Mist & 33.87 & $0.000 * * *$ & 1.30 & $0.250 \mathrm{~ns}$ \\
\hline 21 & Lapc & 40.77 & $0.000 * * *$ & 2.14 & $0.040^{*}$ \\
\hline 22 & $\mathrm{Hpc}$ & 52.32 & $0.000 * * *$ & 3.77 & $0.001 * * *$ \\
\hline 23 & $\mathrm{Hpv}$ & 27.33 & $0.000 * * *$ & 2.33 & $0.026^{*}$ \\
\hline 24 & Hdo & 33.29 & $0.000 * * *$ & 2.44 & $0.019 *$ \\
\hline 25 & Han & 8.59 & $0.000 * * *$ & 1.35 & $0.226 \mathrm{~ns}$ \\
\hline 26 & Hpdc & 37.38 & $0.000 * * *$ & 2.06 & $0.048 *$ \\
\hline 27 & Bado & 60.95 & $0.000 * * *$ & 2.82 & $0.008 * *$ \\
\hline 28 & Baan & 42.96 & $0.000 * * *$ & 2.13 & $0.041 *$ \\
\hline 29 & dopc & 38.12 & $0.000 * * *$ & 2.23 & $0.032 *$ \\
\hline 30 & pcpv & 26.96 & $0.000 * * *$ & 2.13 & $0.040 *$ \\
\hline 31 & pran & 48.74 & $0.000 * * *$ & 2.11 & $0.043 *$ \\
\hline 32 & $c æ c$ & 11.94 & $0.000 * * *$ & 1.75 & $0.098 \mathrm{~ns}$ \\
\hline 33 & brin & 5.55 & $0.000 * * *$ & 0.73 & $0.646 \mathrm{~ns}$ \\
\hline 34 & brsu & 3.02 & $0.007 * *$ & 0.73 & $0.644 \mathrm{~ns}$ \\
\hline 35 & rypc & 17.78 & $0.000 * * *$ & 0.88 & $0.520 \mathrm{~ns}$ \\
\hline 36 & rypv & 6.05 & $0.000 * * *$ & 0.88 & $0.520 \mathrm{~ns}$ \\
\hline
\end{tabular}

Table 2. Results of the comparison sexes and the sites between them obtained by ANOVA for each of the 36 studied variables. Note: $p>5 \%=$ not significant differences, $* p=$ $5 \%$ significant differences, $* * \mathrm{p}=1 \%$ significant differences, $* * * \mathrm{p}=0.1 \%$ significant differences, $\mathrm{F}=$ value of observed $\mathrm{F}$ of the ANOVA, $\mathrm{P}=$ Probability. 


\begin{tabular}{|l|l|l|l|}
\hline Tests & $\begin{array}{l}\text { Value } \\
\text { observed } \\
\text { of the test }\end{array}$ & Fobs & P \\
\hline $\begin{array}{l}\text { Wilks' } \\
\text { Lawley-Hotelling } \\
\text { Pillai's }\end{array}$ & 0.00711 & 7.879 & $0.000 * * *$ \\
\hline
\end{tabular}

Table 3. Multivariate tests used to test the equality of the vectors of average between the sites. ${ }^{* * *} p=0.1 \%$ significant differences, $\mathrm{F}=$ value of the $\mathrm{F}_{\text {obs }}, \mathrm{P}=$ Probability.

\begin{tabular}{|l|l|l|l|}
\hline Tests & $\begin{array}{l}\text { Value } \\
\text { observed } \\
\text { of the test }\end{array}$ & Fobs & P \\
\hline $\begin{array}{l}\text { Wilks' } \\
\begin{array}{l}\text { Lawley-Hotelling } \\
\text { Pillai's }\end{array}\end{array}$ & 0.31937 & 1.087 & $0.181 \mathrm{~ns}$ \\
\hline
\end{tabular}

Table 4. Multivariate tests used to test the equality of the vectors of average between two sexes in the sites. ns: $p$ $>5 \%$ : not significant differences, $\mathrm{F}=$ value of the $\mathrm{F}_{\text {obs }}, \mathrm{P}=$ Probability.

differences existed between the seven sites for all 36 variables.

However, for the sex factor, we concluded that there were no significant differences for 14 variables out of 36 and the existence of significant differences for all 22 variables.

We can conclude as possible a sexual dimorphism between males and females of these 22 variables mentioned above.

Multivariate statistical tests confirm the previous univariate results and show that there are significant differences between sites, whereas for all seven sites, there are no significant differences between the two sexes.

\section{ACKNOWLEDGEMENTS}

At the end of this modest work, I feel both the joy and the duty of thanking all those who have helped me in the development of this study, who have contributed in one way or another to my scientific training.

\section{REFERENCES}

Abla B., Tahar A. \& Mezedjri L., 2018. Comparative Biometrics of a Teleost Fish, Boops boops (Linnaeus, 1758) (Perciformes Sparidae) of the Algerian coast lines. Biodiversity Journal, 9: 121-126.

Arias A. \& Drake P., 1990. Estados juveniles de la ictiofauna en las caños de las salinas de la bahia de Cadiz. CSIC - Instituto de Ciencias Marinas de Andalucía, Junta, 163 pp.

Benzohra M. \& Millot C., 1995. Caracteristics and circulation of surface and intermediate water masses off Algeria. Deep-sea rechearch, 42: 1803-1830.

Choulika M., 2002. Contribution à l'étude de la biologie d'un poisson côtier le Saurel Trachurus trachurus, (Linné, 1758): anatomie et histologie du tube digestif. Mémoire de magister, Université Badji Mokhtar, Annaba 67 pp.

Dagnélie P., 1970. Théorie et méthodes statistiques: applications agronomiques (vol. 2). Gembloux, Presses agronomiques, $451 \mathrm{pp}$.

Dagnélie P., 1986. Analyse statistique à plusieurs variables. Gembloux, Presses agronomiques, 362 pp.

Dagnélie P., 2006. Statistique théorique et appliquée. Tomme 2: Inférences à une et à deux dimensions. Bruxelles-université De Boeck et Larcier, 659 pp.

FAO, 2013. Species Fact Sheets Trachurus trachurus (Linnaeus, 1758), Food and Agriculture Organization of the United Nations. Fisheries and Aquaculture Department.

Grimes S., 2010. Peuplements benthiques des substrats meubles de la côte Algérienne: taxonomie, structure et statut écologique. Thèse de Doctorat, Université d'Oran, Algérie, 362 pp.

Huberty C.J., 1994. Applied discriminate analysis. New York, Wiley, 466 pp.

Korichi H.S., 1988. Contribution à l'étude biologique des deux espèces de Saurels: Trachurus trachurus (Linné, 1758) et Trachurus mediterraneus (Steindachner, 1868) et de la dynamique de Trachurus trachurus (Linné, 1758) en baie de Bou-Ismail (Alger). Thèse de Magister, ISMAL, Alger, 203 pp.

Letaconnoux R., 1951. Contribution à l'étude des espèces du genre Trachurus et spécialement du Trachurus trachurus (Linné, 1758). Office scientifique et technique des pêches maritimes, Mémoire 15: 1-70.

Macer C.T., 1977. Some aspect of the biology of the horse mackerel (Trachurus trachurus) in water around Britain. Journal of Fish Biology, 10: 6162.

Mézédjri L., 2003. Etude Biologique et Biométrique Comparée de l'anchois Européen Engraulis encrasicolus dans le golfe de Stora (Skikda) et le golfe de Lion (France). Mémoire de Magister, Université Badji Mokhtar, Annaba, 106 pp. 
Minitab software statistique, 2013. Version 16 pour Windows.

Palm R., 2000. L'analyse de la variance multivariée et l'analyse canonique discriminante principes et applications. Notes de Statistique et d'Informatique, Gembloux, 2000/1, 40 pp.

Porumb I.J. \& Porumb F.L., 1979. La nourriture du chinchard de la Mer Noire. In: Pora E.A. (Ed.), Le chinchard de la Mer Noire Trachurus mediterraneus ponticus. Etude morphologique. 2ème partie.
Institute Romain de Recherche Marine, 551-611 $\mathrm{pp}$.

Slamene H., Saad Djabellah M., Boughiout B., 2012. Contribution à la biologie (reproduction) de le Saurel, Trachurus trachurus (Linné, 1758), la sardine, Sardina pilchardus (Walbaum, 1792), et l'allache, Sardinella aurita (Valenciennes, 1748) dans le golfe de Skikda, Algérie. Mémoire fin cycle de l'Ingénieur d'état en Sciences de la Mer, Université du 20 Août 1955, Skikda, 89 pp. 